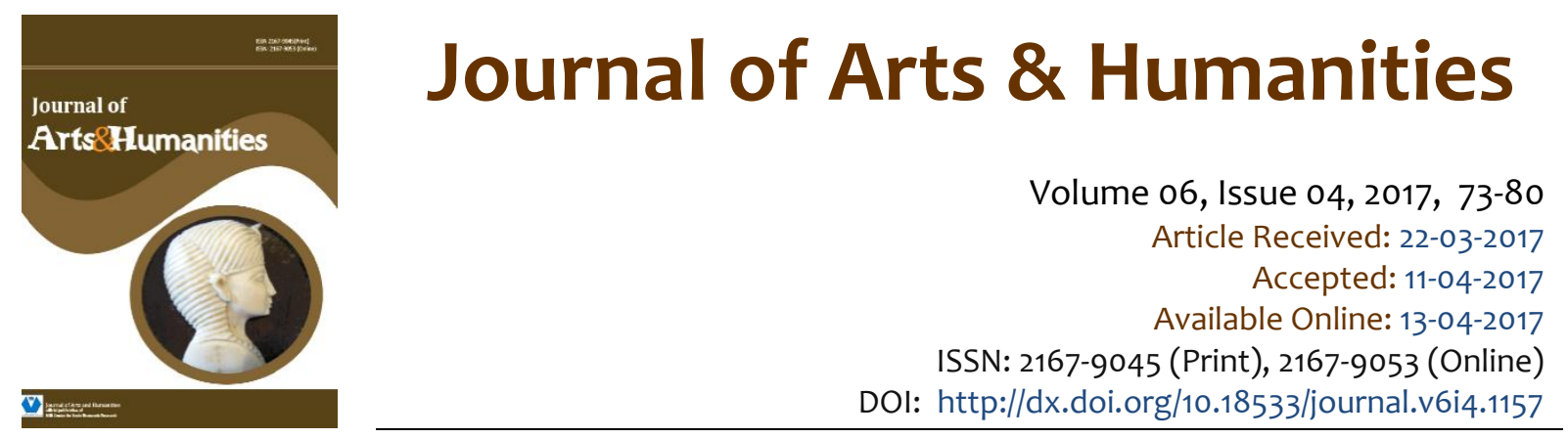

\title{
Time and Quest of Identity of the African-American Character: George Schuyler's Black No More
}

\author{
Hayder Naji Shanbooj Alolaiwi ${ }^{1}$
}

\begin{abstract}
This paper attempts to examine the theme of "passing," viewed as a metaphor of race that marks a step forward from the painful reality of the Middle Passage to "passing," as both physical reality and metaphor, and to find out the underlying causes of the passing character in George Schyler's Black No More in the light of social and historical dimensions. The study investigates the aspects of "passing" manifested by the African-American who is often viewed as an "appendage" to the rest of society, blacks have struggled to attain the success, equality, and overall collective consciousness of the American society, while simultaneously creating and maintaining and identity of their own. Blacks have been and continue to be socially, economically, educationally, and politically disenfranchised and therefore cannot completely find unity within an American system that continuously seeks to reaffirm their inferiority.
\end{abstract}

Keywords: African-American, Blacks, Negros, Passing.

This is an open access article under Creative Commons Attribution 4.0 License.

\section{Introduction}

America has long been called "the Melting Pot" due to the fact that it is made up of a varied mix of races, cultures and ethnicities. The concern here is with the relatively limited diversity caused by largescale immigration of people perceived to be "different" who do not simply melt away into state/nation they have settled among but are ethnically visible and so various multicultural, multiethnic and do not seem to be short term only. The "difference" in question is typically marked by various forms of racism and similar forms of ideologies as the migrants come from societies or groups that have been historically ruled and/or perceived as inferior by the societies into which they have settled.

Several scholars and editors attack this problem from the outset. In 1991, Robert Stepto added two pages of reflection to his 1979 study From Behind the Veil. The brief section, entitled In Terms of Us, begins: "I freely use all the terms I know - Black American, Afro-American, African-American, and so on

\footnotetext{
${ }^{1}$ Faculty of Letters Department of Anglo-American and German Studies, University of Craiova, Craiova, Romania. E-mail: hayder.naji.884@gmail.com
} 
- especially those terms I have "lived under" and "lived in" within my lifetime." But although Stepto may "freely use" all the terms he knows, his practice is pragmatic, his goals realistic: "At certain turns in my work, I will use particular terms to return in time to an era or circumstance, hoping that a carefully chosen term - "Negro," for example - will take my reader on the same journey" (Stepto,1991: xii).

The 1970 edition of Glazer and Moynihan Beyond the Melting Pot does not revise but amends the 1963 study. In the new introduction, the authors address some of the problems of the earlier text: "Where the book failed was in determining what kind of group Negroes would form. As an ethnic group, they would be one of many. As a racial group, as "blacks," as the new nomenclature has it, they would form a unique group in American society." (Glazer and Moynihan 1970:xiii)

My particular interest in this tendency to "blame the victims" involves the use of nomenclature. Glazer and Moynihan highlight their concern about the meaning and direction of "the new nomenclature." Although the authors discuss what might be considered more concrete failures, for instance the perceived "failure of Negroes... to develop and seize the political opportunities open to them" (xviii), their discussion of nomenclature also lays blame at the victim's door. They begin with a vague notion of how blacks see themselves:

"To our minds, whether blacks in the end see themselves as ethnic within the American context, or as only black - a distinct race defined only by color, bearing a unique burden through American history - will determine whether race relations in this country is an unending tragedy or in some measure - to the limited measure that anything human can be - moderately successful." (Glazer and Moynihan 1970:xl)

The authors stress the importance of words, "definitions" and "designations": "Indeed, much of the answer to the question we have posed - ethnicity or racism? - is a matter of definition and selfdefinition, and much of the future of race relations in the city and the country depends on what designations and definitions we use." (xl)

The authors also express specific discomfort with recent changes in racial terminology: "In 1969, we seem to be moving to a new set of categories, black and white, and that is ominous." (xiv) Although Glazer and Moynihan acknowledge the force of self-definition, they do not seem to trust its productiveness. The authors eschew the "ominous" designations of "black" and "white," offering little beyond this negative critique - neither promoting their term-of-choice, "Negro," nor offering other alternatives. Instead, they question the larger meaning and reverberations of the "new nomenclature." But their attention to the Black Power Movement and its adoption of "Black" as a replacement for "colored" or "Negro" conflates racial pride and self-empowerment with racism.

"For just as a 'nigger' can be made by treating him like a 'nigger' and calling him a 'nigger,' just as a black can be made by educating him to a new, proud, black image - and this education is carried on in words and images, as well as in deeds - so can racists be made, by calling them racists and treating them like racists." (xl)

This reductiveness - a conflation of racism and racial pride - typifies the Glazer/Moynihan project. But, despite their negative critique - their great attention to the racialist and racist perceptions of others little attention is given to Glazer and Moynihan's own involvement in racialist systems of thought. As if times had not changed, and as if the authors had not been listening to the efforts of African-Americans to define and determine their own future, the amended 1970 publication of Beyond the Melting Pot, with its new, long introduction, does not revise its own use of terminology.

With the recent conversion of "Black" to "African-American," there has been little distancing of the earlier term, which was, after all, a term adopted by African-American's themselves and from a place of power and pride. But perhaps the present coexistence of these terms suggest a growing under- 
standing that ethnic bonds need not eclipse a simultaneous consideration of the ways our racialist thinking continues to construct our identities and our world. ${ }^{2}$

In contrast to this plurality of meanings, Glazer and Moynihan's challenge to the "ominous" words of "black" and "white" seeks to erase, or rather ignore, reality. Ironically, while the authors express concern for a "new nomenclature," which at the time was associated with Black nationalism, they do not express a similar concern for the older, yet racially evocative term "Negro," which comes from the Spanish for black and often associated with enslavement. ${ }^{3}$

This struggle over signifiers, in which Glazer and Moynihan are representative of the rearguard, is an interesting way to trace a certain history of race. One interesting and illuminating example is given by Kobena Mercer who, in “"1968': Periodizing Politics and Identity", thinks that

"Throughout the modern period, the semiotic stability of this nodal system in racist ideology has been undermined and thrown into a state of dialectical flux as a result of the reappropriation and rearticulation of signs brought about by subaltern subjects themselves. It is precisely around the symbolic displacements of the 'proper name' that we can see the historical formation of new modes of democratic agency. In the United States, this is seen most clearly in the recoding of the proper name - Negro, Colored, Black, Afro-American, and more recently African-American each of which reinflect the connotational value of a given vocabulary in renaming a collective subjectivity in each historical period." (Kobena 1968:p.428)

Irrespective of the theoretical concepts resorted to all along this study, the tools used are those of comparative literature, as clearly defined by Djelal Kadir: "Comparative Literature is the systematic practice of discerning, examining, and theorizing symbolic processes as they affect the material and aesthetic enablements in the production, valuation, and dissemination of literary culture at and through transnational and transcultural sites", with its three main types of methodological precision: (1) intradisciplinarity (analysis and research within the disciplines in the humanities); (2) multi-disciplinarity (analysis and research by one scholar employing any other discipline), and (3) pluri-disciplinarity (analysis and research by team-work with participants from several disciplines) (Kadir, 2001).

\section{The "Crucible"}

The earliest reference to the American melting pot image is found in St. Hector John de Crevecoeur Letters from An American Farmer, published in London in 1782, but written about ten years earlier. In this monograph de Crevecoeur, himself a naturalized American from France, commenting on the mixture of English, Scottish, Irish, French, Dutch, German and Swedish elements that made up the American, "this new man", came with the following explanation:

"... He [the American] is neither a European nor the descendant of a European; hence that strange mixture of blood, which you will find in no other country. I could point out to you a family whose grandfather was an Englishman, whose wife was Dutch, whose son married a French woman, and whose present four sons have now four wives of different nations. He is an American, who, leaving behind him all his ancient prejudices and manners, receives new ones from the new mode of life he has embraced, the new government he obeys, and the new rank he holds... The Americans were once scattered all over Europe; here they are incorporated into one of the finest systems of population which has ever appeared" (Crevecoeur 1951: p.54-55).

\footnotetext{
${ }^{2}$ A recent anthology edited by Gina Dent (Black Popular Culture) provides an "Editor's Note" which shows that the controversy over names is still very much alive, although perhaps now consigned to "notes," "prefaces," and "introductions." The note reads: "In recognition of the contest within African diasporic intellectual production over the meaning of the term 'blackness,' we have allowed a small subset of that debate to live on in the use of both Black with a capital ' $\mathrm{B}$ ' and black with a lowercase 'b' in the essays that follow" (ix).

3 Of the many arguments against this term, probably the most through and impassioned came in 1960 from Richard B. Moore in his study called The Name "Negro": Its Origin and Evil Use.
} 
One century later, Theodore Roosevelt echoed de Crevecoeur's observation, even employing some of his imagery: "We Americans are the children of the crucible." (Roosevelt 1941:p.10) A decade after Roosevelt's remark, the great historian Frederick Jackson Turner reinforced the words of de Crevecoeur and Roosevelt. He wrote that the United States "fused" immigrants "into a mixed race."

Lord James Bryce, the British observer of American life and a one-time ambassador to the United States, in the 1890 s also saw the melting pot's assimilating power. He stated: "What the traveler, and what the Americans themselves delight to point out to him, is the amazing solvent power which American institutions, habits, and ideas exercise upon newcomers of all races." ${ }^{4}$ Then in 1909, Israel Zangwill, the son of Jewish immigrants, wrote a play, The Melting Pot, which played before audiences of several American cities. (See Fig. 1) Everywhere it received high praise. It showed the melting pot as an American reality by portraying the life of David Quixano, a Jewish immigrant in New York absorbing the American culture, its English language, and Weltanschauung, who - in Act I - first defines the notion:

VERA So your music finds inspiration in America?

DAVID Yes - in the seething of the Crucible.

VERA The Crucible? I don't understand!

DAVID Not understand! You, the Spirit of the Settlement! [ He rises and crosses to her and leans over the table, facing her.] Not understand that America is God's Crucible, the great Melting-Pot where all the races of Europe are melting and re-forming! Here you stand, good folk, think I, when I see them at Ellis Island, here you stand I Graphically illustrating it on the table] in your fifty groups, with your fifty languages and histories, and your fifty blood hatreds and rivalries. But you won't be long like that, brothers, for these are the fires of God you've come to - these are the fires of God. A fig for your feuds and vendettas! Germans and Frenchmen, Irishmen and Englishmen, Jews and Russians - into the Crucible with you all! God is making the American. (Act 1) ${ }^{5}$

By the early 1800 s, there were many more African-Americans than there were Africans. It is difficult to guess how many of these AfricanAmericans were the product of mixed-racial parentage. An 1850 census, which hardly solved the problems inherent in racial classifications, "showed mulattoes to be 11.2 percent of the population classified as Negroes. This was based on visibility only, and thus was a gross undercount of all Negroes with some white ancestry" (Davis 2001:p.40). William Craft's narrative from 1860, not to mention Stowe and Brown's varied uses of the publicized event, already suggests the strong fascination whites and blacks had for the passing figure.

\section{The north}

We would like to focus on two novels that came soon after the Depression, and only after countless novels, plays, poems, essays, and

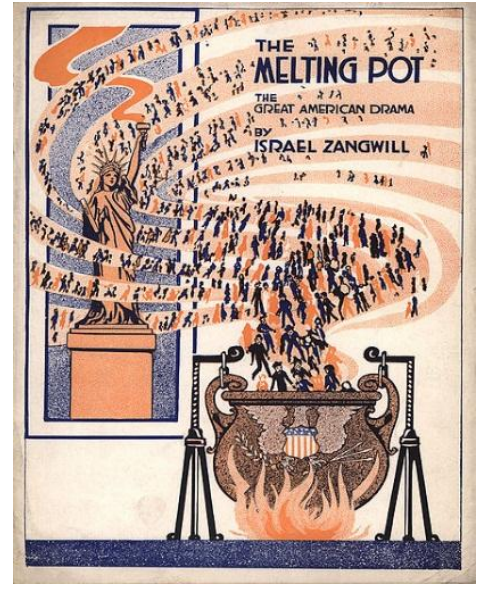

Figure 1 Theatre program for Israel Zangwill's The Melting $\operatorname{Pot}(1916)$ real life situations had already reenacted the drama of "passing" many times over. The first novel, written by a black journalist known for his caustic wit, has been called the "first full-length satire by a black American" (Peplow 1980:p.56). George Schuyler does not so much typify his time as he intensifies it. Born at the end of the last century and having seen the Great War as a first lieutenant, George Schuyler's education, worldliness, and age argue for his inclusion in the Harlem Renaissance pantheon. But Schuyler was also an iconoclast. He began his literary career writing regular columns called "Shafts and Darts: A Page of Calumny and Satire" for The Messenger, as well as "The Simian World" for The

\footnotetext{
4 Gettysburg Address, Nov. 19, 1863, Roy P. Basler et al., eds., The Collected Works of Abraham Lincoln, 8 vols. and an index vol.; (New Brunswick, N.J.: Rutgers University Press, 1953-1955), 7: 93.

5 The Project Gutenberg EBook of The Melting-Pot, by Israel Zangwill. Release Date: December 18, 2007 [EBook \#23893]. <http://www.gutenberg.org/files/23893/23893-h/23893-h.htm>
} 
Pittsburgh Courier. Even "the mentor of the era," ${ }^{6} \mathrm{H}$. L. Mencken, solicited his work for The American Mercury. His purpose was to stir up trouble. While W. E. B. Du Bois was fighting to revalue blackness, Schuyler was denying its very existence. Nonetheless, Du Bois, who was at times criticized and lampooned by Schuyler, said the following of this now overlooked writer: "George Schuyler, so far, is talking things that most people do not want to hear.... One has to read what he says, whether he agrees with it or not." 7

Schuyler begins his "satire on the American race question" with the most pervasive and entrenched beliefs: color defines race; "race" is identity; "passing" is a national preoccupation. He then adds controversy: "Negroes are merely lampblacked Caucasians." And then he confuses the categories: at the end of the novel darkness, through tanning, is a sign of whiteness. Schuyler intensifies the subject of "passing" by, as Du Bois would say, "talking things that most people do not want to hear." "Race" essentially loses meaning in Schuyler's satirical novel of 1931, Black No More: Being an Account of the Strange and Wonderful Workings of Science in the Land of the Free, AD 1933-1940.

Set in the United States of the near future, Schuyler's satire imagines "race" to quite simply disappear with the superficial (and scientific) elimination of blackness. With the invention of a whitening process by Doctor Crookman of Black-No-More, Inc., Negroes become indistinguishable from Caucasians. In contrast to other "passing" narratives from Larson, Hughes, Thurman, Fauset, Johnson, Faulkner, Hurst, and others, Schuyler's characters pass with no trauma, angst, or dilemma. Max Disher, whitened into Matthew Fisher, easily loses his black identity and his sense of community for the nominal fee of fifty dollars. When he leaves the laboratory, he quickly moves from a now foreign Harlem to a very comfortable South. Matthew, rather than struggling against the call of "race" or "heritage," or even "history," answers to the economics of the moment: "He was free! The world was his oyster and he had the open sesame of a pork-colored skin!" (Schuyler 1999:35) To make a living, he easily assumes the role/job of becoming a white supremacist, rising in the ranks of the order, marrying into its first family. Everything is black or white - to quote the cliché - and the extremes of satire seem to perfectly critique the extremes of racialist thinking.

Satire allows no subtleties, and the distance between Max Disher and Matthew Fisher could not be greater. Neither struggles with "race" as do the tormented figures so common to "passing" stories. Nonetheless, Schuyler clearly has modeled Matthew Fisher against such troubled characters as Larsen's Clare and Irene, who complement each other as two halves of a split consciousness. They struggle against each other and within themselves, unlike the trouble-free psyches of Black No More. In fact, no psychological complexity ever enters into Schuyler's characterizations: Black No More cannot risk sympathizing with the conflicts of the "passing" character in its reduction to concepts.

\section{The "Passing"}

More typical of the "passing" genre, Nella Larsen's characters argue what remains implicit in satire. Using twin characters, who can both pass, Larsen creates a dialectic between the racial transgressor and the racial conservator. Irene, a "voluntary Negro," haunts Clare with her rectitude; while conversely Clare teases Irene with her transgressions into white privilege. In their dialectical relationship - the push and pull of their twin desires - civilization alternately supersedes and submits to "race." Larsen's story, like most "passing" stories, not only explores the strain of "black" passing for "white" but "primitive" passing for "civilized." These ambiguities defined the modern sensibility, which felt itself enriched and unsteadied by the existence of other worlds. Black No More struggles with neither the primitive/civilized dichotomy nor with the white/black dichotomy: there are no characters who are caught in between or in conflict with themselves or their communities. Still, Schuyler's satire manages to ask the crucial question implicit in all "passing" dramas. Irene nearly asks it directly, but her

\footnotetext{
${ }^{6}$ Michael Peplow refers to a conversation between Schuyler and himself, at which Schuyler told him that Mencken "was not only the mentor of the era but a personal friend for many years." (42)

7 W. E.B. Du Bois, "The Browsing Reader," The Crisis, 38 (January 1931).
} 
husband makes the real issue explicit: "But why?" Irene wanted to know [why did Irene need to return to her people]. "Why?" "If I knew that, l'd know what race is." (Schuyler 1999:185)

All "passing" stories question the meaning of "race," but Clare - that symbol of ambiguity and instability - has this question riddle her entire existence. She dies, like most passing figures, because she is unsolvable. With its characters quite free of racial allegiances, Black No More does not require the same violent elimination of its protagonist, in part, because there is no crisis of identity. Instead, satire unsteadies the stability of racial meaning, which means we must not look to character or narrative but to the play of concepts. In place of the strain created by a character's dissimulation, Black No More creates friction in the disruption of our expectations. Free of three-dimensional characters who struggle with their identities, Schuyler's satire focuses on ideas. What is required to pass? Who wants to pass? What difference would it make to be "white"? What if everyone were white? How far can passing go? In Black No More, the hypothetical, of course, reaches absurd extremes: "The job (turning America white] was almost complete, except for the black folk in prisons, orphan asylums, insane asylums, homes for the aged, houses of correction and similar institutions." (Schuyler 1999:131)

As blackness becomes more limited to these "institutions," and not present enough in society to make whites feel superior, it becomes necessary to find other definitions of difference. There is a movement to certify the lineage of all Americans in a desperate and last ditch effort to separate "real" Caucasians from fake ones, but it fails because few have a color-free past and fewer still are without mysterious lacunae in their family trees. How can whiteness be legitimized? Ironically, people too white become suspect and whiteness becomes the new liability. This of course brings the reductio ad absurdum full circle and Black No More, which begins with the national craze to whiten, ends with a new, more compelling fad, tanning.

With all these inversion of values, Black No More continuously attacks the many and subtle values that have always undergirded beliefs in "race." Though we are never asked to believe in the "reality" of Schuyler's creation, satire requires that we constantly discern "parody" from "reality," which means readers must find something in life to give meaning (and humor) to Black No More's national craze for "passing" and the ease with which these transformations (or transgressions) occur. Schuyler's satire requires that we examine the very ontological assumptions about "race"; it is difficult to constantly follow Black No More's absurd whitening of America without questioning our own assumptions about "race."

Though traditional "passing" stories also suggest that "race" may be constructed, Black No More requires more reader participation in its active disruption of our expectations of "race." More than any single "passing" narrative, Schuyler's work presents a concentrated attack on old beliefs in "race." All this from an author who had earlier written in Negro-Art Hokum (1926) that "the Aframerican was merely a lampblacked Anglo Saxon," and who throughout his life continued to elide the difference between races in such essays as "The Caucasian Problem" (1944).

Only the subject of race, always viewed through the event of passing, commands Running A Thousand Miles For Freedom. We can think of Stowe and Brown as literary antecedents of Craft's narrative, or we can view "the escape," which was famous, as an antecedent to the novels and the narrative. But how do we locate the first passing event?

It would be difficult to discover the first mention of "passing" or even the first representation of the event of passing. Any history of passing will constantly replace one provisional beginning with another. ${ }^{8}$ Nonetheless, the Craft narrative represents a heightened attention to passing that deserves

\footnotetext{
8 Blyden Jackson's A History of Afro-American Literature is a useful and sobering history that always keeps the question of beginnings in mind. His introduction begins: "It is possible to argue that the story of black Americans and, therefore, AfroAmerican literature, should be considered to extend at least as far back into the West's historic past as A.D. 1441" (1). But this is a vague beginning. In the next chapter, which offers a more tangible literary event, Jackson replaces Jupiter Hammon, who "only a decade or two ago was generally supposed [to be] the first Negro American writer," with Lucy Terry. But even in this
} 
our interest. These vague beginnings share the same cultural time and context as the minstrelsy, and clearly both cultural events testify to the active cross-fertilization of the races, black and white, frequently viewed as diametrically opposite. But the passing plot that Stowe and Brown both used for their novels has a very real analogue in real life.

\section{Conclusion}

To conclude, the "passing" narrative, just like the play of color and the debate over nomenclature, manifests anxiety over the unstable meaning of "race." Rather than providing definition, it destabilizes consensus. It favors instability over the old myths of unity and unproblematic meaning. And finally, it revises outworn stories, ushering in a new scrutiny to old myths. This brief study of the terminology, metaphors, and narratives that are significant to our changing concepts of "race" serves as an introduction to the following readings with their greater attention to the historical significance of the passing narrative.

The narrator of James Weldon Johnson's The Autobiography of an Ex-Colored Man unwillingly witnesses the lynching of a black man by an enraged white mob. No details are given about the crime the victim had presumably committed to deserve such a cruel and unlawful punishment, but it helps the white skinned narrator, who had been jumping to and fro over the color line, to take the most important decision of his life: to stay on the white side:

"All along the journey I was occupied in debating with myself the step which I had decided to take. I argued that to forsake one's race to better one's condition was no less worthy an action than to forsake one's country for the same purpose. I finally made up my mind that I would neither disclaim the black race nor claim the white race; but that I would change my name, raise a mustache, and let the world take me for what it would; that it was not necessary for me to go about with a label of inferiority pasted across my forehead. All the while I understood that it was not discouragement or fear or search for a larger field of action and opportunity that was driving me out of the Negro race. I knew that it was shame, unbearable shame. Shame at being identified with a people that could with impunity be treated worse than animals. For certainly the law would restrain and punish the malicious burning alive of animals" (Johnson, ). 1912: Chapter 10).

There is an on-going debate about who actually counts in the United States, the benefits and problems associated with immigration, and the meaning/legacy of the melting pot have not disappeared since the great wave of European immigration ended in the 1920s. Indeed, the debates in 2004 are sounding a lot like those in 1904. The stakes are high as would-be residents seek to join the American experience, and a new breed of nativist work to preserve what they consider the nation's threatened integrity. A typical reflection of their efforts is the title of a recent newspaper article: "Immigration to cost states seven seats, study claims" (J. Abrams A15). ${ }^{9}$

A spokesman for the anti-immigrant think tank that conducted the study offered such classic nativist scare statements as "[redistribution is a] distortion of the political system in which seats are taken away from citizens and reallocated in effect to noncitizens" and "this can be seen as distorting our democracy." The language of whim and unfairness is consistent throughout: California will "end up" with extra seats, while other states "lost" seats or "failed to get" the ones that were rightfully coming to them. Some states will be "deprived" of their fair representation. New arrivals are jeopardizing the very foundations of the political system.

\section{Source}

new beginning, Jackson is cautious: "In our present state of knowledge about Afro-American literature, we may, and probably should, mark the beginning of that literature with Lucy Terry" (29).

9 Abrams, Jim. “Immigration to Cost States Seven Seats, Study Claims.” Atlanta Journal- Constitution 7 Oct. 1998 : A15. 
Schuyler, George. 1989. Black No More: Being an Account of the Strange and Wonderful Workings of Science in the Land of the Free, AD 1933-1940. Boston: Northeastern University Press.

\section{References}

Crevecoeur, St. H. J. de. (1951). Letters from an American farmer 1782; reprint, New York: E. P. Dutton. pp. 54-55.

Davis, F. James. (2001). Who is black? One nation's definition. University Park: Pennsylvania State University.

Du Bois, W. E. B. (1965). The Souls of Black Folks. In Three Negro Classics. Edited by John Hope Franklin. New York: Avon Books.

Glazer, N. \& Moynihan, D. P. (1970). Beyond the melting pot: The Negroes, Puerto Ricans, Jews, Italians, and Irish of New York City. Cambridge, MA: MIT Press.

Glazer, N. (1971). "Blacks and ethnic groups: The difference and the political difference it makes" .Social Problems 18.

Glazer, N., \& Moynihan, D. P. Schelling. C.S. (1975). Ethnicity: theory and experience. Cambridge, Mass. Harvard University Press.

Jeffrey L. (2001). Rac(e)ing to the right: selected essays of George S. Schuyler. Knoxville: University of Tennessee Press.

Johnson, J. (1912). Chapter 10. The Autobiography of an Ex-Colored Man (Lit2Go Edition). Retrieved April 09, 2017, from http://etc.usf.edu/lit2go/64/the-autobiography-of-an-ex-colored-man/1157/chapter$10 /$

Kadir, D. (2001). Comparative literature, the transnational, and the global. Neohelicon, 28: 25-29. doi:10.1023/A:1011972332300

Mercer, Kobena (1990a) "1968”: Periodizing Postmodern Politics and Identity“, in Lawrenge Grossberg, Cary Nelson, and Paula Treichler (eds.) Cultural Studies, London and New York: Routledge.

Larson, N. (1988). Quicksand and passing. New Brunswick: Rutgers University Press.

Peplow, M. W. (1980). George S. Schuyler. Boston: Twayne Publishers. (Whole book used).

Roosevelt, T. (1941). "American People," in Theodore Roosevelt encyclopedia, ed. Albert Bushnell Hart and Herbert Ferleger. New York: Roosevelt Memorial Association.

Stepto, R.B. (1991). From Behind the Veil: A Study of Afro-American Narrative. Urbana: University of Illinois Press.

Thurman, W. (1929). The blacker the berry: a novel of negro life. New York: Macaulay Co.

Truslow, J. A. (1931). The epic of America, 2nd ed. Westport, CT: Greenwood Press.

Zangwill. I. The melting-pot, The Project Gutenberg EBook. Release Date: December 18, 2007 [EBook \#23893]. <http://www.gutenberg.org/files/23893/23893-h/23893-h.htm>

Zepetnek, S.T. (1998).Comparative literature: theory, method, application. Amsterdam, Atlanta-GA: Rodopi. 